\title{
JÁRÁS SZINTÜ REPREZENTATÍV VIZSGÁLAT A HELYI ÖNKORMÁNYZATOK MEGÚJULÓ ENERGIÁVAL ÉS A KÖRNYEZETVÉDELEMMEL KAPCSOLATOS BERUHÁZÁSAINAK TEKINTETÉBEN
}

\author{
SZEBERÉNYI ANDRÁS
}

\section{Összefoglalás}

A zöld- és megújuló enerigaforrások, valamint a környezettudatosság jelentösége egyre nagyobb szerepet játszik az életünkbe, ahogy haladunk elöre az időben. Fogalmi meghatározás szintjén is, már a legtöbb ember számára érthetö és egyértelmü, hogy mit kellene vagy lehetne tenni a Föld megóvása érdekében. A megújuló energiaforrások használata, mint pl. a nap-, szél-, folyóvizek energiája, illetve a geotermikus energia, mind hozzájárulnak az egyén és a társadalom környezeti értékrendjeinek fejlödéséhez, melyet a környezetröl alkotott tudás és morális meggyözödés alakit ki. Mivel a felelötlen energiapazarló magatartás hosszútávon nem fenntartható, és a természeti eröforrások kimerüléséhez vezethet, igy az alternativ energiaforrások használata nyújthat megoldást erre a világméretü problémára. Ennek okán, a reprezentativ kutatás legföbb célja, a zöld-és megújuló energiaforrások felhasználási és alkalmazási lehetőségeinek vizsgálata, az Észak-magyarországi régióban található Gyöngyösi járás mind a 25 településének esetében. Elsődleges kutatási módszerként kérdöives megkérdezés került alkalmazásra, melynek célja, hogy az önkormányzatok megújuló energiaforrásokkal kapcsolatos beruházásainak mértékét feltárja, illetve, hogy ezek az önkormányzatok milyen egyéb módszerekkel járulnak hozzá a helyi lakosság környezettudattosságának fejlesztéséhez. A kapott eredmények alapján, az önkormányzatok beruházásai szerint a napenergia (pl. napelemek) a leghatékonyabb energiaforrás, amelyet szorosan követ a biomassza felhasználás. A megújuló energiához kapcsolódó fejlesztések és beruházások jelentős mértékben hazai vagy európai uniós pályázati forrásokból valósulnak meg. A jövőben tervezett megújuló energia beruházások összege, a kisebb önkormányzatok esetében várhatóan többnyire 10 - 25 millió forint között lesz, a nagyobb helyi önkormányzatok esetében pedig, több mint 100 millió forint.

Kulcsszavak: megújuló energiaforrások, környezettudatosság, pályázati beruházások, Európai Uniós támogatások

JEL kód: O13, O20, Q28 


\title{
A MICRO-REGION LEVEL REPRESENTATIVE STUDY IN THE CASE OF LOCAL GOVERNMENTS IN THE ASPECT OF RENEWABLE ENERGY INVESTMENTS AND ENVIRONMENTAL PROTECTION
}

\begin{abstract}
The importance of green and renewable energy sources, as well as environmental awareness, is playing an increasing role in our lives as we move forward in time. Even at the conceptual level, it is already understandable and clear to most people what should or could be done to protect the Earth. The use of renewable energy sources, such as the energy of the sun, wind, water, and geothermal energy all contribute to the development of the environmental values of the individual and society, which is shaped by knowledge and moral convictions about the environment. As irresponsible energy-wasting behavior is unsustainable in the long run and can lead to the depletion of natural resources, the use of alternative energy sources can provide a solution to this global problem. For this reason, the main goal of the representative research is to examine the possibilities of using and applying green and renewable energy sources in the case of all 25 settlements of the micro-region of Gyöngyös in the region of Northern Hungary. A questionnaire survey was used as the primary research method, the aim of which is to explore the extent of local governments' investments in renewable energy sources, and what other methods these local governments contribute to the development of environmental awareness of the local population. Based on the results obtained, according to the investments of the local governments, solar energy (e.g. solar panels) is the most efficient energy source, which is closely followed by the use of biomass. Developments and investments related to renewable energy are implemented to a significant extent from domestic or European Union tender sources. The amount of renewable energy investments planned in the future is expected to be between HUF 10 and 25 million in the case of smaller local governments, and more than HUF 100 million in the case of larger local governments.
\end{abstract}

Keywords: renewable energy sources, environmental awareness, tender investments, funds granted by the European Union

\section{Bevezetés}

A zöldenergia napjainkban egyre fontosabb szerepet tölt be az életünkben, mind világszerte, mind hazánkban egyre többször hallani az alternatív energiaforrások, és a környezetvédelem témaköréröl. A megújuló energiaforrások választásával a fogyasztók egy tiszta energia fejlesztését támogatják, amely csökkenti a hagyományos energia előállítás környezetre kifejtett hatásait, és növeli az energetikai függetlenséget [HILARY, 2000]. De ahhoz, hogy minél többen válasszák ezt a fajta energiaformát, meg kell érteni a környezettudatosság szerepét, valamint figyelembe kell venni a környezeti értékek relevanciáját és az ezekhez kapcsolható attitüd, illetve cselekvési hajlandóságot is [MARJAINÉ et al., 2012].

A környezettudatosság tehát a konkrét cselekvések által túlmutat a környezeti tudaton, mert arra törekszik, hogy a társadalom és annak tagjai számára a legmegfelelöbb, hosszú távú környezeti érdekeket megteremtse [KEREKES - SZLÁVIK, 2003]. Az Európai Unió fenntarthatóságot és környezettudatosságot elősegítő céljai is világosak és előremutatóak. 
Elsőként érdemes megemlíteni az Európa 2020 stratégiájának célkitüzéseit, amelyek jelentős szerepet játszottak a környezeti és fenntarthatósági tényezök elösegítésében [SZABÓ - KISS, 2017]. A második ezzel kapcsolatos törekvés az Agenda 2030 ${ }^{1}$, amely 2015 szeptemberében az ENSZ 193 tagállama által elfogadott új integrált fenntartható fejlődési és fejlesztési keretrendszert foglalja magában ${ }^{2}$. Ennek az új keretrendszernek az egyik főbb jellegzetessége, hogy átveszi a fenntartható fejlődési programok szemléletmódját és minden ország számára konkrét célokat és feladatokat ír elő. Ennek középpontjában a Fenntartható Fejlődési Célok (Sustainable Development Goals - SDGs) állnak, melyek minden nemzetre egyaránt érvényesek. Az Agenda összesen 17 konkrét célt fogalmazott meg, melyek közül a 7. cél fontosabb a kutatás szempontjából, ez pedig nem más, mint a „Megfizethető és tiszta energia”. Ezzel összhangban az önkormányzatok is egyre inkább igyekeznek eszerint a cél szerint megvalósítani a hazai és Európai Uniós pályázataikat, illetve igénybe venni azokat ${ }^{3}$.

Az általam felvetett probléma, hogy a környezetszennyező és a felelőtlenül energia pazarló magatartás hosszú távon a természeti erőforrások kimerüléséhez vezet, ezért a fosszilis energiahordozók helyett egyre inkább az alternatív energiaforrások kell, hogy kerüljenek a figyelem középpontjába [TAKÁCS-GYÖRGY et al., 2015]. Ezt az Európai Unió is fokozottan hangsúlyozza, így következetesebb szabályozásokat, adókedvezményeket alkalmaz a megújuló természeti erőforrásokat elősegítő technológiák elterjedésének érdekében [SZAMEK, 2017; ČERYOVÁ et al., 2020]. A reprezentatív primer kutatás célja, hogy járási szinten bemutassa az önkormányzatok hozzállását, és a megújuló enerigával kapcsolatos pályázatok segítségével történő fejlesztési lehetőségeit, illetve az ezekkel kapcsolatos jövőbeni, és a már megvalósított pályázataikat is.

\section{Anyag és módszer}

Kiemelt kezdeti célom volt, hogy felmérjem és megvizsgáljam az Észak-magyarországi régió zöld- és megújuló energia felhasználási, alkalmazási lehetőségeit, mint például a villamosenergiatermelés, üzemanyagként való felhasználás (biodízel, bioetanol), geotermikus-hő hasznosítás (termálvíz), passzív és aktív napenergia hasznosítás (napkollektoros rendszerek), vízenergia felhasználás (vízerőmüvek, vízturbinák), és szélenergia felhasználás (szélerőmü, szélturbina) tekintetében. Ehhez társítottam a környezetvédelem, környezettudatos életmódhoz való hozzáállás és a környezeti fenntarthatósági témaköreit. A kutatás megkezdése után - a kapott eredményeknek köszönhetően - utóbbi témára, földrajzilag pedig Heves megyére, majd a Gyöngyösi járásra szúkítettem le a kutatási területet, mert így nyílt lehetőségem reprezentatív primer kutatás lefolytatására.

Az önkormányzati kutatás 2016 végén kezdődött el [SZEBERÉNYI, 2018], mely során megalapozó vizsgálatokat végeztem a környezeti témakörökre vonatkozóan. Ezen kutatás során kiderült, hogy a megvalósított pályázatok és projektek többsége szoláris panelek telepítését például kórház, művelődési házak, iskolák esetében - vagy biomassza újrahasznosítását foglalta magában. Az előzetes kutatási eredmények rávilágítottak arra is, hogy nagy szükség van az önkormányzatok vizsgálatára, mivel a városok, falvak vezető szerepkörét töltik be, így mindenképpen jelentős vizsgálati faktornak tekinthetők. Továbbá, a helyi lakosok számára is jelentős mértékü iránymutatásként szolgálnak, például a megújuló energiák használatának módszereire, illetve a környezetvédelem fokozására tett eröfeszítéseiket illetően. A kutatás

\footnotetext{
${ }^{1}$ Hivatalos nevén: Transforming our world: The 2030 Agenda for Sustainable Development

${ }^{2}$ Európai Bizottság (2021): https://ec.europa.eu/info/strategy/international-strategies/sustainable-developmentgoals/eu-and-united-nations-common-goals-sustainable-future_en - Letöltve: 2021.02.04.

${ }^{3}$ ENSZ (2021): https://sdgs.un.org/2030agenda - Letöltve: 2021.02.04.
} 
szempontjából további releváns kutatási tényező volt az is, hogy a megkérdezett önkormányzatok aktuális, illetve jövőbeni törekvései, fejlesztései és beruházásai milyen szinten vannak összhangban az Európai Unió által megfogalmazott fenntarthatósági célokkal.

A már előzőekben említett Észak-magyarországi régióban, 3 megye helyezkedik el, amelyekből Heves megye fontos a kutatás szempontjából, illetve ez a megye fel van osztva további 7 járásra (Bélapátfalvai, Egri, Füzesabonyi, Gyöngyösi, Hatvani, Hevesi, Pétervásárai).

Az önkormányzatok esetében tehát járási szintü kutatást végeztem a Gyöngyösi járásban (1.ábra), ahol az összes település önkormányzata közremüködött a kutatásban, ezért az eredmények teljes mértékben reprezentatívnak tekinthetők.

A $751 \mathrm{~km}^{2}$ területü Gyöngyösi járásban található 25 település közül a legközelebbi, mintegy 76 kilométerre esik Budapesttől. A járásszékhely város Gyöngyös, ezen kívül további város még Gyöngyöspata, a többi 23 település pedig községként van nyilvántartva. A 2018-as adatok szerint a népesség száma 69.833 fö, amely 2011-től 2016-ig átlagosan 600 fővel csökkent évente, majd 2018-ra ez mérséklődött évenkénti 135 före, de továbbra is folyamatosan csökken a járás lakosságának száma. 2005-ben a lakosság száma 77.249 fő volt, de elsősorban a főváros munkaerő-elszívó hatása miatt ez a szám 2018-ra mintegy 69.833 före csökkent. A járásban található legnagyobb község típusú település Nagyréde, melynek népessége 3197 fő volt, illetve a legkisebb település Mátraszentimre, melynek népessége 416 fő volt 2018-ban [TeIR, 2020].

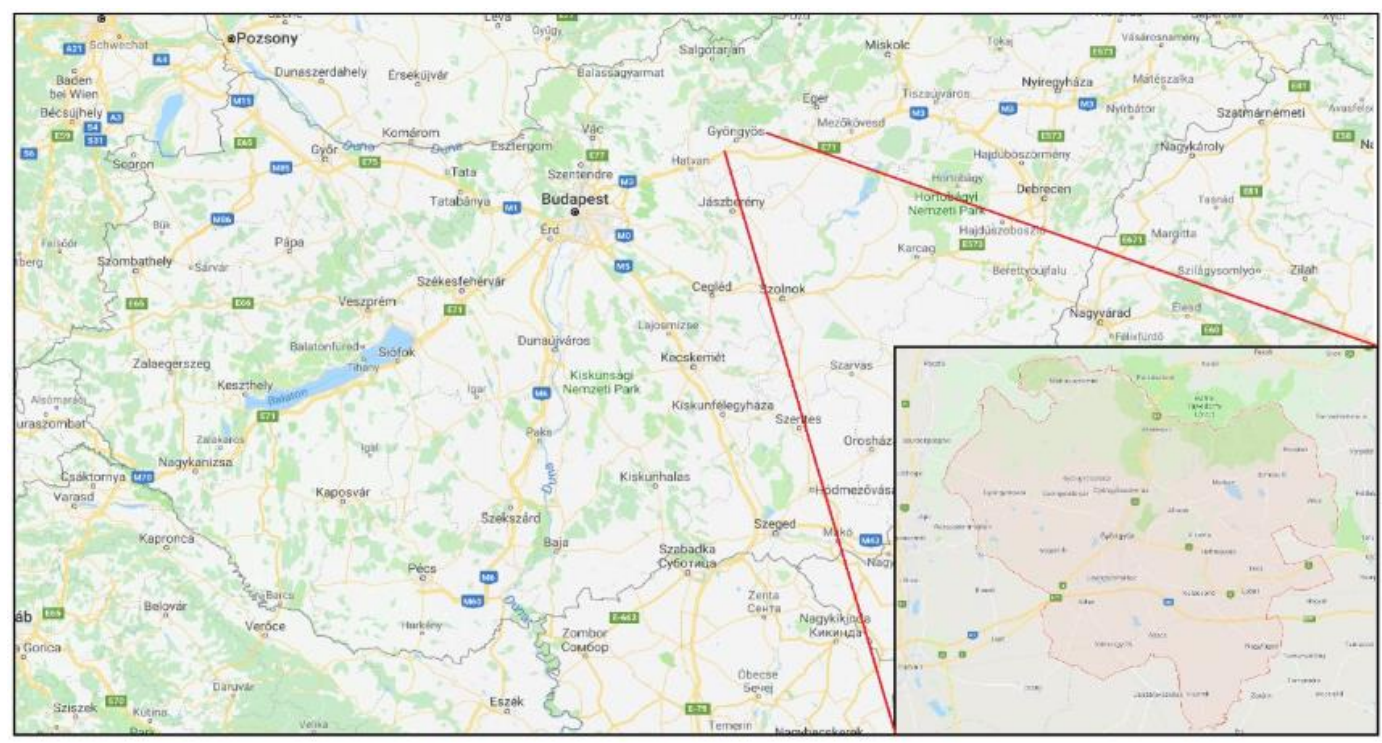

1. ábra: A Gyöngyösi járás elhelyezkedése

Figure 1. Location of the micro-region of Gyöngyös

Forrás: Google Maps alapján saját szerkesztés, 2020

A kutatás ezen tanulmányban bemutatott része a 2018/2019-es időintervallum között valósult meg. A kérdöíves kitöltések személyesen, egyénenként történtek, mivel így egyúttal lehetőség nyílt a bővített, interjú típusú megkérdezés lefolytatására is, ahol további hasznos információkat osztottak meg az érintett önkormányzati vezetők. A kérdőív témakörökre osztott, mely első sorban a megújuló energiák általános és célzott használatára tér ki, valamint, hogy az önkormányzatok esetében, az ezzel kapcsolatos beruházások - amennyiben voltak - milyen forrásokból valósultak meg, illetve nagyságrendileg mekkora összegüek voltak ezek a beruházások, és milyen további lehetőségeik vannak az ezzel kapcsolatos tenderek megpályázására. 
Mivel több település esetében is összevont önkormányzatok vannak a falvak méretei miatt, így ezek összetétele három típus szerint kategorizálható. Az elsőbe azon városok tartoznak, amelyek különálló önkormányzattal rendelkeznek, ebből összesen kettő van. A második típusba azon falvak tartoznak, amelyek szintén rendelkeznek különálló önkormányzattal, ezekből összesen tizenkettő van. A harmadik típusba pedig azok a falvak tartoznak, amelyek különálló önkormányzattal nem rendelkeznek, ezekből pedig összesen tizenegy van.

Az előzetes szakirodalom, a saját gyakorlati tapasztalatom, valamint az előzetes kutatások alapján az alábbi hipotézisek igazolására/elvetésére törekszem:

1. Hipotézis: A helyi önkormányzatok határozott szerepet játszanak a lakosság környezettudatosságának és környezetvédelemmel kapcsolatos hozzáállásának a befolyásolásában a vizsgált térségben.

2. Hipotézis: Az Európai Unió környezettel kapcsolatos céljainak elérését a terület-és vidékfejlesztési programok/pályázatok a vizsgált térség szintjén elösegítik.

Az önkormányzatokkal kapcsolatos fontosabb kutatási célok, illetve az ezekhez jól illeszkedő kutatási kérdések összegzése az 1. táblázatban látható.

\section{1. táblázat: A kutatás logikai keretrendszere / Table 1. Logical framework of research}

\begin{tabular}{|c|c|c|}
\hline Kutatási cél (Research objectives) & Kutatási kérdés (Research question) & $\begin{array}{l}\text { Vizsgálati } \\
\text { módszer } \\
\text { (Research } \\
\text { method) }\end{array}$ \\
\hline $\begin{array}{l}\text { A Gyöngyösi járásban a vidék- és } \\
\text { területfejlesztés szempontjából kiemelt } \\
\text { célcsoportként az önkormányzatok } \\
\text { vizsgálata a megújuló energia, a } \\
\text { környezet-tudatosság és a } \\
\text { környezetvédelem témája mentén. } \\
\text { (In the micro-region of Gyöngyös, local } \\
\text { governments are a priority target group } \\
\text { for rural and regional development, with } \\
\text { a focus on renewable energy, } \\
\text { environmental awareness and } \\
\text { environmental protection.) } \\
\text { Az online eszközök és módszerek } \\
\text { lehetőségeinek feltárása a } \\
\text { környezettudatosság erösítésében. } \\
\text { (Exploring the potential of online tools } \\
\text { and methods in promoting environmental } \\
\text { awareness.) }\end{array}$ & $\begin{array}{l}\text { K1: Milyen az önkormányzatok helyzete } \\
\text { és szerepe a környezettudatosság } \\
\text { tekintetében? (Q1: What is the position } \\
\text { and role of local governments with regard } \\
\text { to environmental awareness?) } \\
\text { K2: Hogyan lehet a környezeti problémák } \\
\text { megelözéséhez, megoldásához lokálisan } \\
\text { (önkormányzatok, szintjén) hozzájárulni? } \\
\text { (Q2: How is it possible to contribute to the } \\
\text { prevention and solution of environmental } \\
\text { problems at local (governmental) level?) } \\
\text { K3: A környezettudatosság kapcsán } \\
\text { milyen szerepet kap/kaphat az online } \\
\text { kommunikáció és az online média? } \\
\text { (Q3: What is the role of online } \\
\text { communication and online media in } \\
\text { relation to environmental awareness?) }\end{array}$ & $\begin{array}{l}\text { Kérdőíves felmérés } \\
(\mathrm{N}=25), \\
\text { leíró statisztika, } \\
\text { tartalomelemzés } \\
\text { (nyitott kérdésekre } \\
\text { vonatkozóan) } \\
\text { ((Questionnaire } \\
\text { survey ( } \mathrm{N}=25), \\
\text { descriptive } \\
\text { statistics, content } \\
\text { analysis (for open } \\
\text { questions)) }\end{array}$ \\
\hline
\end{tabular}

Forrás: Saját kutatás és szerkesztés, 2020

\section{Eredmények}

A helyi önkormányzatok esetében tehát nagyon fontos, hogy kivegyék a szerepüket a megújuló energiára vonatkozó fejlesztések előmozdításában, úgy, mint egyfajta példa a helyi lakosok számára. Így a primer kutatásom egyik fó célja volt, hogy a járásban található összes önkormányzat hozzáállását megvizsgáljam erre vonatkozóan. 
Az önkormányzatok számára készített kérdőív 23 kérdésből áll, amelynek első része a megújuló energiaforrások használatának formáira, azok forrásainak kivitelezésére, az ezzel kapcsolatosa beruházások és pályázatok mértékére kérdez rá, illetve a kérdőív második részében kitértem a talaj- és vízminőségre, a szelektív hulladékgyüjtés módszereire, a levegő minőségére fütési időszakban, a helyi szintü környezetvédelem és megújuló energiák támogatásának hozzáállására, valamint, hogy az önkormányzatok használják-e az online kommunikációban és a közösségi médiában rejlö lehetőségeket a lakossággal való kommunikációra. Minden kérdőív személyesen lett kitöltetve, amelyek eredményeit szóbeli megkérdezések formájában egészítettem ki, így ezek a személyes kitöltések egyfajta interjú módszerként is értelmezhetők. A településeket tekintve a járásban található mind a 25 település hozzájárult a kérdőív kitöltéséhez, így a primer kutatásom teljes mértékben reprezentatívnak tekinthetö. A 25 vizsgált településböl kettő (8\%) város, huszonhárom $(92 \%)$ pedig falu. A járásban több falu is összevont önkormányzattal rendelkezik, amelyek esetében annyi kérdőívet töltöttem ki, ahány falu tartozik az adott önkormányzathoz. Így, ezen metodika szerint a vizsgált települések 56\%-a rendelkezik önálló önkormányzattal, 44\% pedig nem rendelkezik (további részletes felosztásban lásd: Anyag és Módszertan).

Az önkormányzatoknak szánt felméréshez tartozó első kérdés esetében arra voltam kíváncsi, hogy az önkormányzatok vagy az önkormányzatok által fenntartott intézmények közül használják-e valamelyik megújuló energiaforrást az általam felsoroltak közül, és ha igen, akkor melyik fajtáját, illetve, hogy hol. A 25 megkérdezett önkormányzat esetében a 2. táblázatban jelölt három energiaforrást használják, a legtöbbet a biomassza és a napenergiára vonatkozóan.

\section{2. táblázat: A kutatásban részt vett helyi önkormányzatok által használt megújuló energiaforrások megoszlása felhasználás helye szerint}

Table 2. Renewable energy sources used by the local governments involved in the research - Distribution by place of use

\begin{tabular}{|c|c|}
\hline $\begin{array}{l}\text { Energiaforrás fajtája } \\
\text { (Type of energy } \\
\text { source) }\end{array}$ & Felhasználás helye (Place of use) \\
\hline $\begin{array}{r}\text { Biomassza } \\
\text { (Biomass) }\end{array}$ & $\begin{array}{ll}- & \text { önkormányzati épületek (municipal buildings) } \\
\text { - } & \text { óvodák (nurseries) } \\
\text { - } & \text { polgármesteri hivatalok (mayor's offices) } \\
\text { - } & \text { kastély (castle) } \\
\text { - } & \text { egészségházak (health centres) } \\
\text { - } & \text { orvosi rendelők (doctor’s offices) } \\
\text { - } & \text { tornatermek [beépített fütés] (gyms [build-in heating]) } \\
\text { - } & \text { általános- és középiskolák (primary and secondary schools) } \\
\text { - } & \text { integrált közösségi terek (integrated community spaces) } \\
\text { - } & \text { szolgáltatói terek (service spaces) } \\
\end{array}$ \\
\hline $\begin{array}{c}\text { Biogáz, } \\
\text { (Biogas) }\end{array}$ & $\begin{array}{ll}\text { - } & \text { szennyvíztisztító telep (waste water treatment plant) } \\
\text { - } & \text { uszoda épületek (swimming pool buildings) }\end{array}$ \\
\hline $\begin{array}{l}\text { Nap } \\
\text { (Solar) }\end{array}$ & $\begin{array}{l}\text { - napelemek az óvodák és általános iskolák épületein (solar panels on nursery } \\
\text { and primary school buildings) } \\
\text { - napelemek és napkollektorok az önkormányzati épületeken vízmelegítés } \\
\text { céljából (solar panels and collectors on municipal buildings for water heating) }\end{array}$ \\
\hline $\begin{array}{l}\text { Nem használ } \\
\text { (Do not use) }\end{array}$ & $\begin{array}{l}\rightarrow \text { öt önkormányzat, akik nem használnak semmilyen megújuló energia-forrást } \\
\text { (five local governments that do not use any renewable energy sources) }\end{array}$ \\
\hline
\end{tabular}


A lehetséges válaszok közt szerepelt a geotermikus, a víz és a szélenergia is, de a primer kutatás időpontjában ezek közül egyiket sem használták az érintett önkormányzatok. Lényegesnek tartom megemlíteni, hogy a személyes beszélgetések által kapott információ során többen is kiemelték, hogy a legnagyobb hatékonysággal a nap (föleg a szoláris panelek) által nyert energia az, ami felhasználható, ezt követően pedig a biomassza. Ennek egyik okaként kiemelték a falvak elhelyezkedését, mivel a Mátra-hegységhez közel helyezkednek el, így a tengerszint feletti magasság miatti elönyök jobban érvényesíthetővé válnak, és a napsütéses órák száma is megfelelö. A kapott eredmények továbbá rávilágítanak, hogy a biomassza leginkább önkormányzati épületekben, polgármesteri hivatalokban, egészségházakban, óvodákban, iskolákban, integrált közösségi- és szolgáltatói terekben, valamint orvosi rendelökben használatos, de egy esetben kastélyban is (Nagyréde). A 25 megkérdezett önkormányzatok 20\%-a nem használ semmilyen megújuló energiaforrást, aminek okaira a későbbiek során fogok kitérni.

Vizsgáltam, hogy ezeket a fejlesztéseket és beruházásokat, milyen forrásból valósították meg az önkormányzatok. A nyitott kérdés jellegéből adódóan a válaszadók többféle pályázati forrást megadhattak. Fentebb már említésre került, hogy a megújuló energiára vonatkozó pályázati beruházások esetében 20 önkormányzat vett részt, így az 1. ábrán csak ezen önkormányzatok megoszlása látható.

A kapott eredmények alapján a 20 önkormányzat összesen 35 megújuló energiára vonatkozó beruházást valósított meg, amelyek a következők szerint lettek kategorizálva:

\author{
Európai Uniós pályázati forrás $(23 \%)$ \\ KEHOP pályázati forrás (14\%) \\ TOP pályázati forrás $(9 \%)$ \\ Hazai pályázati forrás $(34 \%)$ \\ Saját önkormányzati forrás $(20 \%)$
}
$\rightarrow 8$ helyi önkormányzat esetében
$\rightarrow 5$ helyi önkormányzat esetében
$\rightarrow 3$ helyi önkormányzat esetében
$\rightarrow 12$ helyi önkormányzat esetében
$\rightarrow 7$ helyi önkormányzat esetében

A megújuló energiára vonatkozó fejlesztések, beruházások jelentős mértékben (34\% - ld. 2. ábra) valamilyen hazai pályázati forrásból (például Széchenyi 2020) valósultak meg, átlagosan 70-90\%-os támogatási szinttel, amely esetben a maradék 10-30\%-ot az önkormányzatoknak saját forrásból kellett fedezniük. Amennyiben nem sikerül a pályázatban leírtakat megfelelöen teljesíteni az elbírálási folyamat során - nem csak, hogy vissza kell fizetni a pályázati összeget, de ezen felüli büntetésre is számíthat az önkormányzat.

Az Európai Uniós forrás volt a második legtöbbet igénybe vett pályázati forrás, mintegy 23\%-ban, amely több esetben is, például Mátraszentimre és Nagyréde településeken, 100\%-os pályázati támogatást tett lehetővé. Ez az egyéb költségeket is - mint például szakemberek megkeresése, ajánlatkérés, az érintett épületek állapotának felmérése, a napelemek telepítése, karbantartása, a kötelező periodikus vagy garanciális problémák kezelése stb. - teljes mértékben fedezte. A finanszírozási formák esetében, az összes pályázat $20 \%$-át tették ki a saját önkormányzati források, leginkább a biomassza és a fütéstechnológia korszerüsítésére vonatkozó fejlesztések tekintetében. Kombinált pályázati források alkalmazása is előfordult, például Markaz (TOP 3.2.1-16+ saját önkormányzati forrás használata) Gyöngyös (EU+ KEHOP+ hazai pályázatok + saját önkormányzati források) és Vámosgyörk (EU + KEHOP + saját önkormányzati forrás) esetében, ahol vagy egymásra épülő, némely esetben pedig egymást kiegészítő megújuló energiára vonatkozó pályázatokat tudtak megvalósítani. 


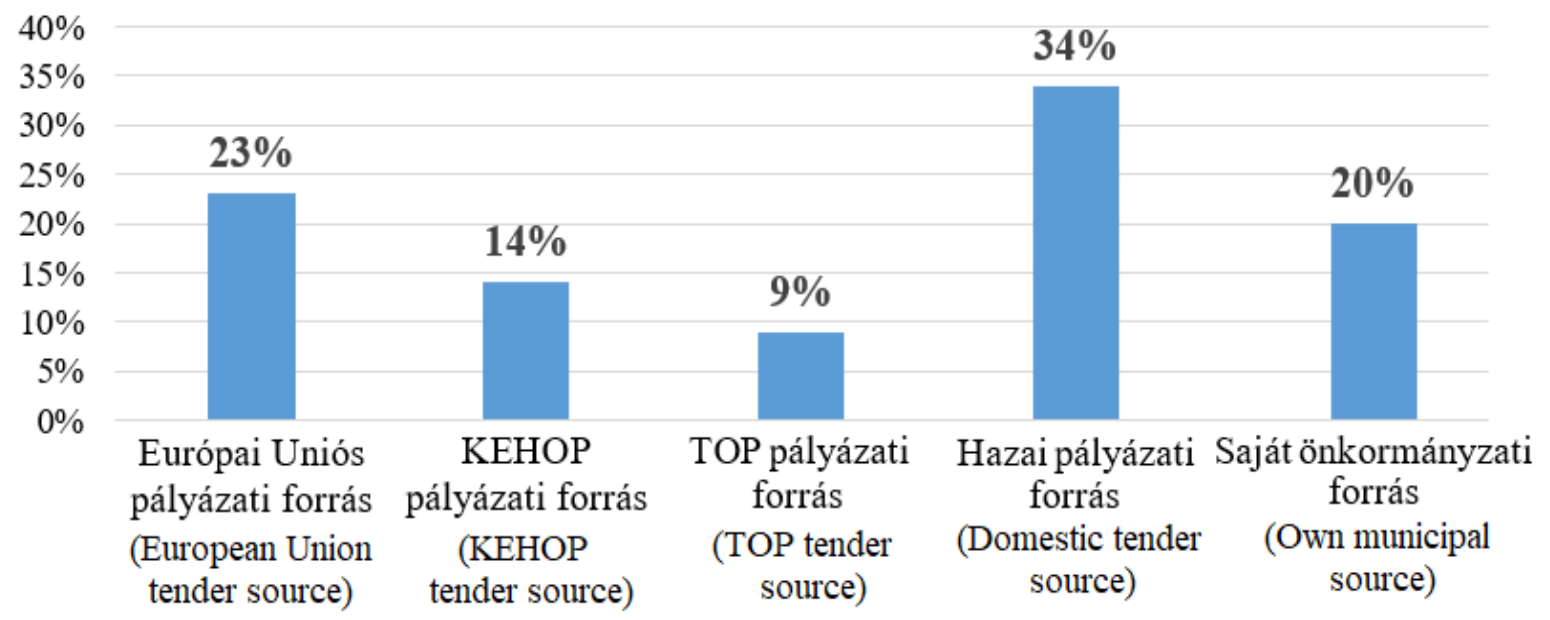

\section{2. ábra: A megkérdezett helyi önkormányzatok által igénybe vett} pályázati források megoszlása (\%)

Figure 2. Distribution of tender funds used by the asked local governments (\%)

Forrás: Saját kutatás és szerkesztés, 2020

A primer kutatás következő kérdése a beruházás megtérülésére vonatkozott, amely éves megtakarítás szintjén volt meghatározva. A 3. ábrán látható megoszlás eredményeiben 20 önkormányzat volt érintett. Az önkormányzatok 5\%-ának állítása szerint nagyjából kevesebb, mint 2 év kell ahhoz, hogy megtérüljön a beruházás. A megkérdezett helyi önkormányzatok 20\%-a gondolja úgy, hogy nagyjából 2-3 év alatt megtérül a fejlesztésekbe invesztált összeg, amely a biomassza és biogáz esetében már valóságosabb adatnak tekinthetö, illetve napenergia esetén, ha nagyon hatékony. A legtöbb önkormányzat, mintegy 35\% úgy ítéli meg, hogy nagyjából 4-5 év alatt térül meg a beruházásra szánt összeg, amely a napenergiára vonatkozóan már közelebb áll a valódi időtartamhoz ${ }^{4}$, de ahhoz, hogy ez valóban megtörténjen, kimagasló mennyiségü napsütéses óraszámra van szükség, és a termelt áram megfelelő tárolásának módjára. Utóbbira két lehetséges módszer létezik: az egyik, az áram visszatáplálása a hálózatba, amely előnye, hogy nem környezetszennyező, mivel valaki más felhasználja a hálózaton a napelemek által termelt zöldenergiát, de hátránya, hogy ha a rendszer és az érintett épület/ingatlan a központi villamoshálózattól független (mert nincs kiépítve), akkor energiatárolást érintő problémák jelentkezhetnek. Az általam vizsgált megújuló energiát használó önkormányzatok $85 \%$-a ezt a módszert használja.

A második módszer a szigetüzemü tároló-rendszer, aminek legnagyobb előnye, hogy akkumulátorok segítségével teljes mértékben függetleníteni tudják magukat az önkormányzatok a közüzemi hálózattól (annak díját is beleértve), és a hálózat-kimaradási zavaroktól. Hátránya, hogy az akkumulátorokat nagyjából 5-10 évente (kapacitás és típustól függően) szükséges cserélni, illetve, a beépített napelem-teljesítményt nem elég 85-90\%-os teljesítményre előtervezni (ezért a legtöbb esetben többszörösen is túl kell kalibrálni, hogy az évszakok közötti fogyasztás-termelés különbözőségei kitermelődjenek). Az általam vizsgált helyi önkormányzatok 15\%-a használja ezt a módszert, azok közül, amelyek napenergiát használnak. Az önkormányzatok 25\%-a vélekedik úgy, hogy több, mint 5 év szükséges a

\footnotetext{
${ }^{4}$ A napelemek átlagos élettartama 8-12 év, amely optimális esetben kitermeli a beruházásra szánt összeget ebbe nem számítandó bele a viszontagságos időjárás okozta (pl. jégeső) vagy más emberi tényező miatt történő rongálódás (pl. nem megfelelő telepítés, hibás kialakítás), amely torzítja a napelemek élettartamára vonatkozó statisztikai adatokat.
} 
beruházási költségek megtérülésére, és vannak olyan önkormányzatok is (15\%), akik már a pályázatok igénybevételekor tudták, hogy sosem fog megtérülni a beruházásuk, de mégis megvalósították, mivel a pályázatokban elöírt kritériumok között nem, vagy részben szerepeltek megtérülésre vonatkozó pontok, így mindenképpen megérte ez a fajta fejlesztés.

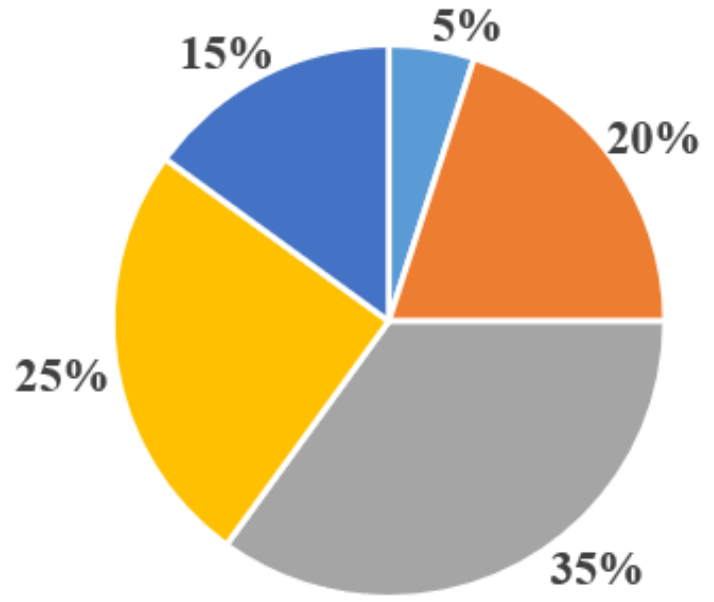

- kevesebb, mint 2 év (less than 2 years)

- nagyjából 2-3 év (approx. 2-3 years)

- nagyjából 4-5 év (approx. 4-5 years)

- több, mint 5 év (more than 5 years)

- soha nem térül meg (will never pay off)

\section{3. ábra: A pályázati beruházások átlagos megtérülésének időtartama (\%) \\ Figure 3. Average duration of return on tender investments (\%)}

Forrás: Saját kutatás és szerkesztés, 2020

Ehhez kapcsolódóan érdemes a szóbeli interjúk alapján megemlíteni, hogy a kisebb falvaknak sokkal nehezebb megújuló energiára vonatkozó tenderekre és fejlesztésekre pályázniuk, mivel számos olyan követelmény van elöírva, amelyet nem tudnak teljesíteni (pl. önkormányzati épületek állapota, nem megfelelő strukturális szerkezet miatti telepítés problémák, önkormányzati önrész hiánya stb.). Ezt jól mutatja az is, hogy a járásban található 25 település közül 5 semmilyen ezzel kapcsolatos pályázatban nem tudott részt venni a kutatás időpontjáig bezárólag. További problémaként említették a szakemberek hiányát, és az emiatt kialakuló várakozási időt, mivel sok esetben a tenderek, csak a kiépítésre vonatkozó költségeket fedezik, a későbbi időszakos karbantartások és az ezekkel járó egyéb költségeket, valamint a szakemberek munkadíját/bérezését viszont nem.

A következő kérdés a pályázati beruházások átlagos összegét vizsgálja, amelynek megoszlása a 4. ábrán látható. A kérdés hat kategória szerint lett meghatározva, amelyből öt vonatkozik valamilyen összegre, a hatodik opció pedig a „nem tervez beruházást”, de ez nem releváns az ábra esetében.

Az ábra alapján megállapítható, hogy a kutatás során megkérdezett önkormányzatok 40\%-a esetében 10 millió Ft-nál kevesebb volt a beruházás mértéke, amely 8 önkormányzatot érint. Valamelyest nagyobb beruházás volt az önkormányzatok 30\%-a esetében, amely 10 millió Ft és 25 milliót Ft közötti beruházási összeget jelentett. 15\% esetében 25,01 millió Ft és 50 millió Ft között volt, további 10\% esetében pedig már relatív magasnak számító összeg, 50,01 millió Ft és 100 millió Ft közötti összeg volt a beruházások és fejlesztések mértéke. 


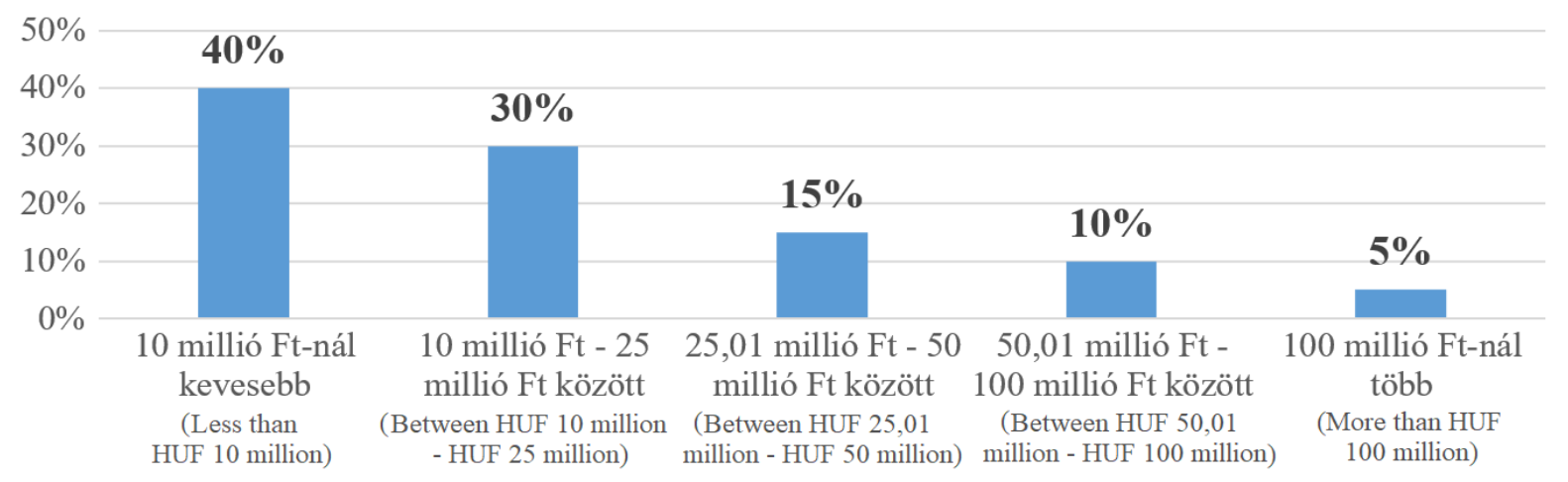

\section{4. ábra: A beruházások átlagos összegének megoszlása a vizsgált önkormányzatok esetében $(\%)$}

Figure 4: Distribution of the average amount of investments in case of the examined local governments $(\%)$

Forrás: Saját kutatás és szerkesztés, 2020, $n=20$

Csak egyetlen önkormányzat volt, amely meghaladta a 100 millió Ft-os beruházási összegkeret összesített értékét. Több esetben említésre kerültek a kérdéssel kapcsolatos problémák tényezői, amely kiemelten a saját pénzügyi források hiányát emelte ki. További felmerülő problémaként megemlítették még a közbeszerzéssel kapcsolatos finanszírozási problémákat (önerő hiánya); a már előzőekben megemlített szakemberek és felügyeleti szervek hiányát (pl. nem lehet energiatermelö, vagy csak bizonyos kritériumok teljesítése esetén lehet az); a már telepített napelemek esetében nincs szakember, aki rendszeresen ellenőrizni tudná; a pályázat során felmerülő elszámolási nehézségeket, utólagos fedezethiányokat; a már telepített eszközök, panelek meghibásodásának megfelelö körülmények közti javítása, cseréje sok esetben csak részben vagy egyáltalán nem lehetséges; általánosságban jellemző a nagyon hosszú és körülményes ügymenet, amely sok esetben hetek, hónapok, drasztikusabb esetben akár 1 év is lehet; illetve, a fenntartási idő alatt az önkormányzatok évente kötelesek elszámolni az irányítóhatóság felé, amely rengeteg plusz adminisztrációs feladattal jár.

A következő két kérdést logikusabbnak ítéltem meg, ha együtt ábrázolva mutatom be, mivel erősen kapcsolódnak egymáshoz, és ebben az esetben már mind a 25 önkormányzat érintett volt. A kérdés arra vonatkozott, hogy a jövőben terveznek-e valamilyen megújuló energiára vonatkozó beruházást az önkormányzatok, és ha igen, akkor milyen jellegü beruházást.

A kérdöívben eredetileg négy saját energiaforrás típust határoztam meg, de a kapott eredmények alapján ötre módosítottam (3. táblázat), mivel több önkormányzat esetében is tervben vannak LED-es technológiával kapcsolatos beruházások. Minden energiaforrás típushoz társítottam a hozzá tartozó beruházások átlagosan tervezett mértékét, illetve a felhasználás helyeit. Bár a kérdőívben kitértem a szélenergiával kapcsolatos beruházásokra, de az eredmények szerint egy önkormányzat esetében sincs tervezet ezzel kapcsolatos beruházásra vagy fejlesztése, ezért ezt a csoportot kizártam. A legnagyobb és egyben legtöbb helyen tervezett beruházás - energiaforrás típus szerint - a napelemek és napkollektorok telepítésével kapcsolatos fejlesztésekre vonatkozik, átlagosan 2 millió Ft és 75 millió Ft között (2-7 millió Ft Gyöngyöstarján, Pálosvörösmart; 8-30 millió Ft Gyöngyösoroszi, Mátraszentimre; 31-75 millió Ft Gyöngyös, Vámosgyörk, Visonta), felhasználásuk helye szerint leginkább általánosés középiskolákban (pl. melléképületek oldalán vagy tetején, tornaterem tetején, hátsó udvaron külön kialakított részen), önkormányzati és orvosi rendelők épületein, valamint egészség- és kultúrházakon. 
Járás szintü reprezentatív vizsgálat a helyi önkormányzatok megújuló energiával és a környezetvédelemmel kapcsolatos beruházásainak tekintetében

\section{3. táblázat: A jövőbeni megújuló energiára vonatkozó beruházások mértéke és helye a megkérdezett önkormányzatok esetében}

Table 3. Extent and location of future renewable energy investments in the case of the asked local governments

\begin{tabular}{|c|c|c|}
\hline $\begin{array}{l}\text { Energiaforrás típusa } \\
\text { (Type of energy source) }\end{array}$ & $\begin{array}{l}\text { Beruházás mértéke } \\
\text { (Extent of investment) }\end{array}$ & $\begin{array}{l}\text { Felhasználás helye } \\
\text { (Place of use) }\end{array}$ \\
\hline $\begin{array}{l}\text { Hőszigetelés; bojler, ablak és } \\
\text { ajtócserével kapcsolatos } \\
\text { fejlesztések, beruházások: } \\
\text { (Thermal insulation; boiler, } \\
\text { window and door replacement } \\
\text { improvements and investments:) }\end{array}$ & $\begin{array}{l}\text { átlagosan } 5 \text { millió Ft és } 35 \text { millió Ft } \\
\text { közötti összeg } \\
\text { (average amount between HUF } 5 \\
\text { million and HUF } 35 \text { million) }\end{array}$ & $\begin{array}{l}\text { - általános iskolákban (primary schools) } \\
\text { - müv. központokban (cultural centres) } \\
\text { - óvodákban (nurseries) }\end{array}$ \\
\hline $\begin{array}{l}\text { Biomasszával kapcsolatos } \\
\text { beruházások: } \\
\text { (Biomass investments:) }\end{array}$ & $\begin{array}{l}\text { átlagosan } 1 \text { millió Ft és } 10 \text { millió Ft } \\
\text { közötti összeg } \\
\text { (average amount between HUF } 1 \\
\text { million and HUF } 10 \text { million) }\end{array}$ & $\begin{array}{l}\text { - középiskolákban (secondary schools) } \\
\text { - orvosi rendelőkben (doctor’s offices) } \\
\text { - egészségházakban (health centres) }\end{array}$ \\
\hline $\begin{array}{l}\text { Szélenergiával kapcsolatos } \\
\text { beruházások: } \\
\text { (Wind energy investments:) }\end{array}$ & $\begin{array}{c}\text { nem volt ezzel kapcsolatos beruházás } \\
\text { (there was no related investment) }\end{array}$ & $\begin{array}{l}\text { nem volt ezzel kapcsolatos beruházás } \\
\text { (there was no related investment) }\end{array}$ \\
\hline $\begin{array}{l}\text { Napelemek és napkollektorok } \\
\text { telepítésével kapcsolatos } \\
\text { beruházások: } \\
\text { (Investments in the installation of } \\
\text { solar panels and solar collectors:) }\end{array}$ & $\begin{array}{c}\text { átlagosan } 2 \text { millió Ft és } 75 \text { millió Ft } \\
\text { között } \\
\text { (average amount between HUF } 2 \\
\text { million and HUF } 75 \text { million) }\end{array}$ & $\begin{array}{l}\text { - általános iskolákon (primary school) } \\
\text { - önkorm. épületeken (mncp. buildings) } \\
\text { - falvak/városok föterein (main squares) } \\
\text { - orvosi rendelökön (doctor’s offices) } \\
\text { - parkokban (parks) } \\
\text { - egészségházakon (health centres) } \\
\text { - óvodákon (nurseries) } \\
\text { - mủv. központokon (cultural centres) }\end{array}$ \\
\hline $\begin{array}{l}\text { Egyéb, LED-es technológiával } \\
\text { kialakított világítás fejlesztése: } \\
\text { (Other, Development of other } \\
\text { lighting using LED technology:) }\end{array}$ & $\begin{array}{c}\text { átlagosan } 500 \text { ezer Ft és } 3 \text { millió Ft } \\
\text { között } \\
\text { (average amount between HUF } 500 \\
\text { thousand and HUF } 3 \text { million) }\end{array}$ & $\begin{array}{l}\text { - óvodákban (nurseries) } \\
\text { - általános iskolákban (primary schools) } \\
\text { - középiskolákban (secondary schools) } \\
\text { - parkokban (parks) } \\
\text { - főtereknél, nagyobb világítótestek } \\
\text { esetében (main squares - for larger } \\
\text { luminaires) }\end{array}$ \\
\hline
\end{tabular}

\section{Megjegyzés: Több válasz is megjelölhetö volt!}

Forrás: Saját kutatás és szerkesztés, 2020

A napelemek után a LED-es technológiára vonatkozó világítás (közterek, föterek, épületek, belső terek) fejlesztésére vonatkozó beruházások szintén sok település által szerepelnek a tervek között, melynek beruházási mértéke 500 ezer Ft és 3 millió Ft közötti összegre tehetö, leginkább óvodák, iskolák, parkok és főterek esetében.

A hőszigetelés, ablak és ajtócserével, fütéstechnológiára vonatkozó újítások szinte minden település esetében érvényesek. Ebben az esetben két típust különböztetek meg egymástól: azok a falvak és városok, amelyek már végrehajtották ezen típusú fejlesztéseket egy részét vagy egészét, illetve, akik tervezik ennek részét vagy egészét megtenni.

A 25 település közül kiemelendő Detk, Nagyréde, Pálosvörösmart és Visonta, akik ezzel kapcsolatos beruházásaik nagy részét már megvalósították, így inkább a többi kategóriában szeretnének pályázni. Ezzel szemben Abasár, Atkár, Gyöngyös, Gyöngyöspata, Gyöngyössolymos, Gyöngyöstarján, Markaz, Mátraszentimre és Vámosgyörk már jelentős mértékü beruházást hajtott végre erre a típusra vonatkozóan, de nem sikerült elegendő támogatást kapnia a teljes épületekre vonatkozó felújításra, ezért a későbbi 2021-es periódusban további tendereket terveznek. A fennmaradó 14 település (Adács, Domoszló, Gyöngyöshalász, Gyöngyösoroszi, Halmajugra, Karácsond, Kisnána, Ludas, Nagyfüged, Nagyréde, Szücsi, Vécs, Visznek) egyáltalán nem, vagy csak kevés mértékü beruházást tudott megvalósítani az elmúlt időszakos tenderekből, de mindegyik helyi önkormányzat tervez erre vonatkozó beruházást a jövőben. 
A jövőbeni megújuló energiára vonatkozó beruházások megtervezéséhez tartozik az is, hogy nagyjából mekkora beruházást terveznek a megkérdezett önkormányzatok. Erre külön kérdésben is kíváncsi voltam (ez nem egyezik a 3. táblázat - „beruházás mértéke” kategóriával, mivel a 4. táblázat esetében az összes tervezett beruházásra vonatkozó mérték van meghatározva), amely esetben 6 különböző kategória közül választhattak az önkormányzatok, 5 esetben konkrét összegre vonatkozóan, illetve szerepelt a „nem tervez” opció is, de ezt egy önkormányzat sem jelölte meg, tehát mindegyik tervez valamilyen megújuló energiára vonatkozó beruházást. A kategóriák felosztását és a hozzájuk tartozó települések önkormányzatainak tervezési összegeit a 4. táblázatban mutatom be.

A kapott eredményekböl jól látszik, hogy 2020-tól a Gyöngyösi járásban található helyi önkormányzatok jelentős része 25 millió $\mathrm{Ft}$ fölötti megújuló energiaforrásra vonatkozó beruházást tervez. Viszonyításképp érdekes szempont, hogy a falvak mérete és az ott élő emberek száma sok esetben jelentősen eltér - például: 2019-ben Gyöngyös lakossága 29036 fö volt, amely a járásban található legnagyobb város, míg Visonta lakossága 1250 fő, amely az egyik legkisebb falu - mégis mindkét település 100 millió Ft-nál nagyobb beruházást tervez. Ennek egyik lehetséges oka a visontai Mátrai Erőmü jelenléte, amely mindenképpen pályázati elönyökhöz juttatja a települést. Jellemzően jól látszik, hogy a kisebb falvak többsége, amelyek lakosságszáma 3000 fö alatt van, 10 millió Ft-nál kevesebb mértékü beruházást terveznek.

A szóbeli interjúk során, egyik problémaként emelték ki a polgármesterek az önrész hiányát, amely jelentős mértékben limitálja a tenderekben való részvétel eredményességét. További probléma, hogy a tenderek egy része egymásra épül, ezért mindaddig, amíg az első szintet nem tudják megvalósítani, addig a következő beruházást sem tudják megpályázni, így folyamatosan blokkolva a folyamat sikerességét.

\section{4. táblázat: Az önkormányzatok jövőbeni tervezett megújuló energiaforrásokra vonatkozó beruházásainak mértéke}

Table 4. Extent of the local governments' planned future investments in terms of renewable energy sources

\begin{tabular}{|l|l|}
\hline \multicolumn{1}{|c|}{$\begin{array}{c}\text { Tervezett beruházás mértéke } \\
\text { Extent of planned investments) }\end{array}$} & $\begin{array}{l}\text { Településhez tartozó helyi önkormányzatok } \\
\text { (Local governments belonging tot he municipality) }\end{array}$ \\
\hline $\begin{array}{l}10 \text { millió Ft-nál kevesebb } \\
\text { (less than HUF } 10 \text { million) }\end{array}$ & $\begin{array}{l}\text { Adács, Atkár, Domoszló, Halmajugra, Kisnána, } \\
\text { Ludas, Nagyfüged, Visznek }\end{array}$ \\
\hline $\begin{array}{l}10 \text { millió Ft és } 25 \text { millió Ft között } \\
\text { (between HUF } 10 \text { and } 25 \text { million) }\end{array}$ & $\begin{array}{l}\text { Gyöngyösoroszi, Gyöngyöstarján, Karácsond, } \\
\text { Markaz, Szücsi, Vécs }\end{array}$ \\
\hline $\begin{array}{l}\text { 25,01 millió Ft és } 50 \text { millió Ft között } \\
\text { (between HUF } 25,01 \text { and } 50 \text { million) }\end{array}$ & $\begin{array}{l}\text { Abasár, Gyöngyöshalász, Gyöngyöspata, } \\
\text { Mátraszentimre, Pálosvörösmart }\end{array}$ \\
\hline $\begin{array}{l}50,01 \text { millió Ft és } 100 \text { millió Ft között } \\
\text { (between HUF } 50,01 \text { and } 100 \text { million) }\end{array}$ & Detk, Nagyréde \\
\hline $\begin{array}{l}100 \text { millió Ft-nál több } \\
\text { (more than HUF } 100 \text { million) }\end{array}$ & $\begin{array}{l}\text { Gyöngyös, Gyöngyöstarján, Gyöngyössolymos, } \\
\text { Vámosgyörk, Visonta }\end{array}$ \\
\hline $\begin{array}{l}\text { Nem tervez beruházást } \\
\text { (No planned investment) }\end{array}$ & \\
\hline
\end{tabular}

Forrás: Saját kutatás és szerkesztés, 2020 
A következő kérdésben arra voltam kíváncsi, hogy az adott beruházási ötletek kapcsán milyen forrásokból tájékozódnak az önkormányzatok. A válaszokat tekintve elég széles spektrumot kaptam, melyeket szöveges elemzéssel összegzek. Mivel a kérdés nyílt típusú volt, ezért több válasz is adható volt, így a megoszlás összege nem $100 \%$-ot tesz ki. A kérdésre mind a 25 önkormányzat válaszolt.

Tehát, a legáltalánosabb forrás, amely a vizsgált önkormányzatok 36\%-ára jellemző, hogy külön szakembert foglalkoztat, aki folyamatosan a pályázati felhívásokat figyeli vagy más szakemberektöl, hírforrásokból tájékozódik. 16\% kiemelte, hogy a környezetvédelmi államtitkár írta ki tenderként a középületek energetikai korszerüsítését, aminek próbálnak megfelelni a pályázatok megvalósításával. Az önkormányzatok 20\%-a említette meg, hogy valamilyen elözetes pályázatból kiindulva nyílt lehetőségük egy másik pályázat megvalósítására, illetve 44\%, az előző polgármester tervezete alapján „megörökölte” a feladatot, aminek következtében próbálja megvalósítani a beruházást.

A következő két kérdés szorosan kapcsolódik egymáshoz. Kíváncsi voltam arra, hogy az önkormányzatoknak milyen aktuális környezetvédelmi problémáik vannak helyi szinten, valamint, hogy a település része-e valamelyik tájvédelmi körzetnek vagy nemzeti parknak, amely a járáshoz tartozik, és ha igen, melyiknek. A kutatás eredményei alapján megállapítható az a probléma - amelyet sok falu aktív környezetvédelmi problémaként említ -, hogy hetente egyszer vagy többször is, szemetet és zöldhulladékot égetnek a lakosok, amely nagyon rossz hatással van a levegö minőségére. Ezt tovább rontják a téli időszakban a fütésre vonatkozó módszerek, amely esetében szintén szeméttel fütenek (leginkább spórolás miatt), ezért sok faluban elviselhetetlen füstös köd van jelen. Az önkormányzatok szerint ennek megoldására helyi, országos, vagy EU szintü szabályozásra lenne szükség - törvény szintjén - mivel az életminőségre is hatással van a rossz levegő minősége, ami hosszútávon tüdő és egyéb szervi megbetegedéseket okoz.

Sajnos, Gyöngyös egyik nagyon régi és jelenleg is aktuális problémája a város szélén elhelyezkedő szennyvíztelep, melynek csatornájából folyamatosan szivárog a szennyvízlé, ezáltal pedig kellemetlen szaghatást idéz elö a környéken. Ebben a problémában Gyöngyöshalász is érintett, ezért mindkét település próbált már intézkedéseket tenni ennek valamilyen szintű mérséklésére, de sajnos a környezeti hatások, a Gyöngyös-patak jelenléte és kiszámíthatatlansága - sokszor megakadályozza ezt. Említésre került továbbá az esővíz nem megfelelő elvezetése a csatornarendszerbe, ami rengeteg kárt csinál, és sok esetben az önkormányzat pénzéből kell megoldani a kár helyreállítását. A vadállatok szaporulata, és az általuk okozott károk is több helyen említésre kerültek, amely nem folyamatos, inkább időszakos problémának tekinthető, leginkább tavasszal és ősszel. Ilyenkor rendkívül megugrik a közúti balesetek száma járás szinten, amely sok esetben halálos kimenetelü. Ennek megoldásaként körforgalmak kialakítását javasolnák az önkormányzatok az érintett részeken (pl. Gyöngyös - Gyöngyöshalász, Gyöngyössolymos - Pálosvörösmart, Gyöngyös Gyöngyöstarján - Gyöngyöspata vonalak találkozásánál, ahol különösen magas a balesetek száma).

A kutatás során vizsgáltam azt is, hogy a 25 település része-e valamilyen tájvédelmi körzetnek vagy nemzeti parknak. A Gyöngyösi járás esetében ez mindenképpen releváns, mivel a Mátra körzete sok települést érint. A Mátrai Tájvédelmi Körzet 1985-ben lett védetté nyilvánítva, területe pedig 11841 ha, és részét képezi a Bükki Nemzeti Parknak [BNPI, 2020]. A tájvédelmi körzet 12 település közigazgatási területét érinti, amelyből számomra 6 releváns a vizsgált járás szempontjai miatt (Domoszló, Gyöngyös, Gyöngyössolymos, Kisnána, Markaz, Mátraszentimre). 
A természetvédelmi problémákat tekintve szóbeli interjú formájában megemlítették a biológiai sokféleség és az erdőterületek csökkenését, a faszénégetés, hamuzsírfőzés következtében. Szakmai tapasztalat alapján elmondták, hogy bár a vágásos üzemmódú erdőgazdálkodás még mindig a gazdasági érdekeket tartja szem előtt - ami jelentős mértékben ellentétben áll a természetvédelmi törekvésekkel - kisebb-nagyobb területeken már próbálnak természetközeli gazdálkodási módokat folytatni, aminek célja, hogy folyamatosan biztosítva legyen az erdőborítás, természetese újulat megjelenésével és növekedésével felhasználva.

A Natura 2000 hálózat célja, hogy az eltűnéssel fenyegetett, vagy kis kiterjedésű természetes élőhelyek, veszélyeztetett, sérülékeny vagy bennszülött fajok hosszú távú fennmaradását biztosítsa, illetve megőrizze a biológiai sokféleséget. A Natura 2000 területekre vonatkozó szabályokat a 2004. október 8-án kihirdetett 275/2004. (X.8.) kormányrendelet tartalmazza.

A következő három kérdés szintén kapcsolatban áll egymással, mely esetben arra voltam kíváncsi, hogy a vizsgált településeken van-e központi szennyvízelvezetés/szennyvíztisztító, és ha van, akkor milyen forrásból építették ki, valamint, hogy javult-e a települési környezet vízminősége a kiépítés után. A kérdés nyitott jellegéből adódóan több forrást is írhattak az önkormányzatok. Összességében elmondható az eredmények alapján, hogy 4 települést kivéve (Atkár, Domoszló, Halmajugra, Szücsi) minden településen van szennyvízelvezetés /szennyvíztisztító, amelyeket kevés esetben Európai Uniós (9\%) és állami (14\%) pályázati forrásból építettek ki, jelentős mennyiségben pedig hazai (20\%), illetve önkormányzati (48\%) pályázati forrásokból finanszíroztak. Az erre vonatkozó összes igénybe vett pályázati forrás 44 $\mathrm{db}$ volt. A 4 település közül, amely nem rendelkezik központi szennyvízelvezetéssel /szennyvíztisztítóval, Atkár, a jövőben sem tervez erre vonatkozó beruházást, míg Domoszló, Halmajugra és Szücsi tervez.

Minden település esetében, ahol található központi szennyvízelvezetés/szennyvíztisztító egyértelmüen sokat javult a vízminőség (92-98\%-os rákötöttségi szinten), valamint csökkent az élővizek és a talaj szennyezettsége. Gyöngyösön 2006 után javult a legtöbbet a vizek minősége egy nagyobb beruházás után. Mátraszentimre egyedi helyzetben van, mivel egészen a Mátrahegység sürüjében helyezkedik el a település, így természetes források veszik körbe, ami jelentős mértékben - természetes körforgásos módon - javítja a vízminőséget.

A leginkább téli időszakra jellemző kérdést illetően (5. táblázat) - amely a levegő minőségére vonatkozott fütési időszakban - a vizsgált települések 12\%-a mondta azt, hogy nem tudja pontosan vagy bizonytalan a levegő minőségének megítélésében. A települések 40\% úgy ítéli meg, hogy nagyjából ugyanolyan vagy kicsit rosszabb csak a levegő minősége a fütési időszakon kívüli időszakokhoz képest. Ezen falvak esetében jellemző, hogy rendszeresen van légmozgás, valamint szinte mindig jó minőségü fával fütenek, így az egészségkárosító anyagok (szén-monoxid, kátrány, nehézfémek stb.) kevésbé maradnak bent a településen. A többi település szerint (48\%) sokkal rosszabb a helyzet a fütési időszakban, aminek okaként több mindent is felsoroltak. Ilyenek például, hogy lakosság egy része visszatért a rossz, vizes, kevert minőségü fával való tüzelésre, amelynek tökéletlen égése miatt a káros füst rossz hatással van a levegő minőségére. Vannak, akik szénnel vagy hulladékkal tüzelnek (pl. müanyag, kartonpapír), ami még ennél is károsabb az egészségre, mivel nehézfém-ionokat is tartalmaznak, melyek tartós belégzése tüdőrákot és egyéb, súlyos betegségeket okozhatnak. 
Járás szintű reprezentatív vizsgálat a helyi önkormányzatok megújuló energiával és a környezetvédelemmel kapcsolatos beruházásainak tekintetében

\section{5. táblázat: A levegő minőségére vonatkozó eredmények megoszlása fütési időszakban a vizsgált települések esetében \\ Table 5. Distribution of air quality results during the heating period in the case of the examined settlements.}

\begin{tabular}{|c|c|c|c|}
\hline & $\begin{array}{c}\text { Kicsivel rosszabb, mint } \\
\text { fütési időszakon kívül. } \\
\text { (Slightly worse than } \\
\text { outside the heating } \\
\text { season.) } \\
\end{array}$ & $\begin{array}{l}\text { Sokkal rosszabb, mint } \\
\text { fütési időszakon kívül. } \\
\text { (Much worse than outside } \\
\text { the heating season.) }\end{array}$ & $\begin{array}{c}\text { Nem tudom } \\
\text { megítélni. } \\
\text { (I can not judge.) }\end{array}$ \\
\hline $\begin{array}{c}\text { Települések } \\
\text { (Settlements) }\end{array}$ & $\begin{array}{l}\text { Atkár, Detk, } \\
\text { Gyöngyöspata, } \\
\text { Gyöngyössolymos, } \\
\text { Karácsond, Markaz, } \\
\text { Mátraszentimre, } \\
\text { Nagyréde, Vámosgyörk, } \\
\text { Vécs }\end{array}$ & $\begin{array}{l}\text { Abasár, Adács, Gyöngyös, } \\
\text { Gyöngyöshalász, } \\
\text { Gyöngyösoroszi, } \\
\text { Gyöngyöstarján, } \\
\text { Halmajugra, Kisnána, } \\
\text { Ludas, Nagyfüged, Visonta }\end{array}$ & $\begin{array}{l}\text { Domoszló, Szücsi, } \\
\text { Visznek }\end{array}$ \\
\hline $\begin{array}{c}\text { Megoszlás } \\
\text { (Distribution) }\end{array}$ & $\begin{array}{l}10 \text { település } \\
\text { (10 settlements)- } 40 \%\end{array}$ & $\begin{array}{l}12 \text { település } \\
(12 \text { settlements })-48 \%\end{array}$ & $\begin{array}{l}3 \text { település } \\
(3 \text { settlements) }-12 \%\end{array}$ \\
\hline
\end{tabular}

Forrás: Saját kutatás és szerkesztés, 2020, $n=25$

Az önkormányzatok esetében szükségesnek tartottam megkérdezni továbbá, hogy náluk, hogyan müködik, mit gyüjtenek külön, illetve, hogy milyen további szinten tudják támogatni a környezetvédelmet. A kapott eredmények alapján - saját logikai határvonalat alkotva - az 5. ábra mutatja be a települések szelektív hulladékgyüjtésre vonatkozó jellemzőit, ahol a zöld jelöli a jól müködő, hatékony szelektív hulladékgyüjtést, a pirossal jelölt települések pedig, ahol kevésbé vagy egyáltalán nem müködik.

Az ábrán jól látszik, hogy a szelektív hulladékgyüjtés „epicentruma” Gyöngyös, ahol a többi településhez képest régebb óta müködik ez a folyamat. Ez azt jelenti a gyakorlatban, hogy külön szállítják a kommunális hulladékot és külön a szelektívet, különböző napokon, hetente egyszer, illetve több helyen vannak hulladékgyüjtő udvarok a veszélyes hulladékok számára (akkumulátor, elemek, olajok, hütőfolyadék stb.), ahova külön is el lehet vinni az ebbe a kategóriába tartozó hulladékokat. Az ábrán látható továbbá, hogy a Gyöngyös vonzáskörzetébe tartozó települések - Abasár, Adács, Atkár, Detk, Gyöngyöshalász, Gyöngyössolymos, Halmajugra, Karácsond, Markaz, Nagyréde, Pálosvörösmart, Vámosgyörk, Visonta - szintén müködik a szelektív hulladékgyüjtés, amely esetekben jellemzően a kommunális hulladékot hetente egyszer, míg a PET palackot, mủanyagot, üveget külön viszik el két-három hetente. Lomtalanítást is tartanak évente egyszer, és pályázati forrásból finanszírozva lehetőséget biztosítanak a lakosság számára, hogy két gyüjtő legyen minden ingatlannál, amelyből az egyik a háztartási hulladék számára, a másik pedig a mủanyag, papír és üveg kategóriába tartozó szemétnek van fenntartva.

Az ábrán látható pirossal jelzett településekre nem jellemző a szelektív hulladékgyüjtés, amelynek egységesen elmondható oka például, hogy az érintett települések nem tudják finanszírozni a külön szemétszállítást, mivel túl messze vannak a lerakodó telepek a településektől, illetve nagyobb probléma, hogy az önkormányzatok nem rendelkeznek megfelelő összegű önerővel, mivel nem tudnak pályázni az ezt érintő tenderekre. Ez alól kivételt képez Mátraszentimre, amely esetében egyáltalán nem müködik a szelektív hulladékgyüjtés, mert túl magasan helyezkedik el a település a Mátra-hegységben. 


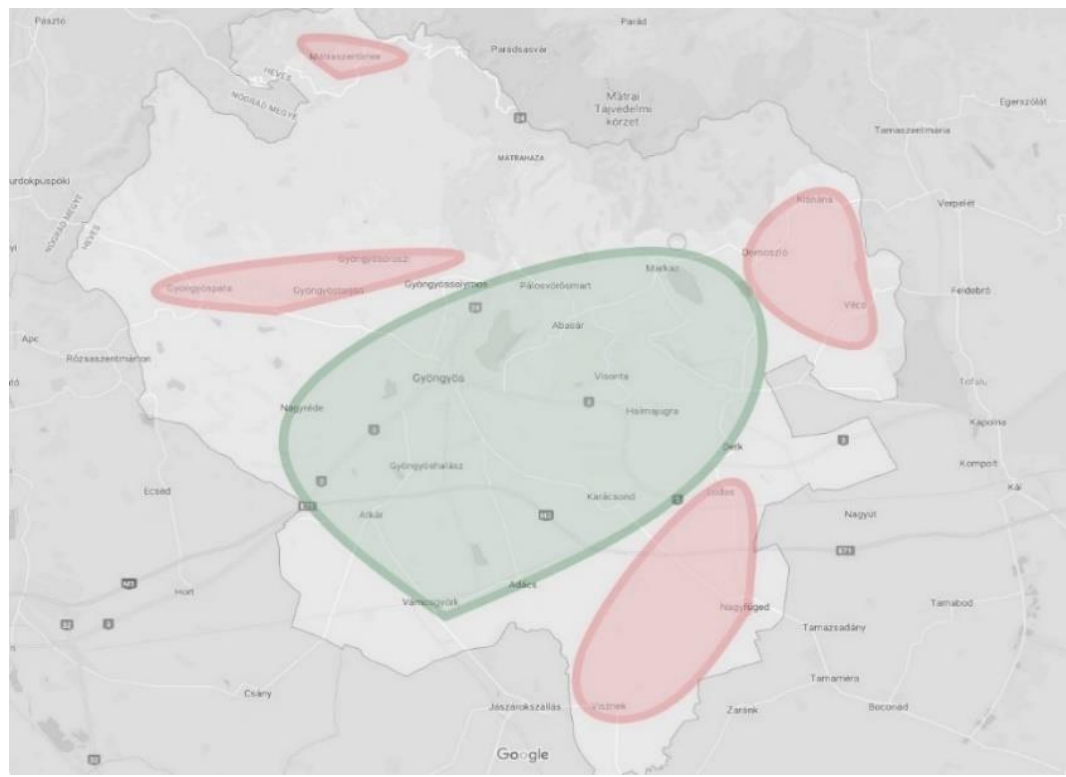

\section{5. ábra: A vizsgált településeken működő szelektív hulladékgyüjtés hatékonyságának területi megoszlása}

Figure 5. Territorial distribution of the efficiency of selective waste collection in the examined settlements

Jelmagyarázat: - pirossal jelölt részeken nem müködik a szelektiv hulladékgyüjtés

- zölddel jelölt részeken müködik a szelektiv hulladékgyüjtés

Explanation: - no separate waste collection in the areas marked in red

- areas marked in green are covered by separate waste collection

Forrás: Saját kutatás és szerkesztés, 2020

Bár a települések egy része limitált lehetőségekkel rendelkezik a hulladékkezelés szempontjait tekintve, de ez nem gátolja meg az önkormányzatokat abban, hogy helyi szinten támogassák a környezetvédelmet. Négy különböző tényezőre bontva ábrázoltam a 6 . táblázatban, hogy az önkormányzatok mivel és milyen szinten támogatják ezt, illetve, hogy melyek azok, amelyek nem támogatják a helyi szintü környezetvédelmet.

\section{6. táblázat: A vizsgált önkormányzatok környezetvédelemre fókuszáló tényezői Table 6. Factors of the examined local governments with a focus on environmental protection}

\begin{tabular}{|c|c|}
\hline Tényezők (Factors) & Települések (Settlements) \\
\hline $\begin{array}{l}\text { A településen található óvodák, általános-, és a középiskolák is } \\
\text { támogatják szemétszedés által, környezetvédelmi programokkal } \\
\text { [zöld óvoda, iskola], amely a gyerekek tudatos neveléséhez is } \\
\text { hozzájárul. (Nurseries, primary and secondary schools in the } \\
\text { settlement are also supported by litter picking and environmental } \\
\text { programmes [green nurseries, school], which also contribute to } \\
\text { the conscious education of children.) }\end{array}$ & $\begin{array}{l}\text { Abasár, Gyöngyös, Gyöngyössolymos, } \\
\text { Markaz, Nagyréde, Pálosvörösmart, } \\
\text { Szücsi, Vámosgyörk, Visonta, Visznek }\end{array}$ \\
\hline $\begin{array}{l}\text { A településen élö helyi lakosság különösképpen odafigyel a } \\
\text { környezetvédelemre, amelyet az önkormányzatok is támogatnak } \\
\text { és finanszíroznak, például, külön környezetvédelmi alapot } \\
\text { létrehozva. (The local population is particularly attentive to } \\
\text { environmental protection, which is also supported and financed } \\
\text { by the local governments, for example by setting up a special } \\
\text { environmental fund. ) }\end{array}$ & $\begin{array}{l}\text { Detk, Gyöngyös, Karácsond, Markaz, } \\
\text { Mátraszentimre, Nagyréde, } \\
\text { Pálosvörösmart, Vámosgyörk }\end{array}$ \\
\hline
\end{tabular}




\begin{tabular}{|l|l|}
\hline $\begin{array}{l}\text { Országos programokhoz, pályázatokhoz csatlakoznak; } \\
\text { szemétgyüjtési akciókat terveznek, hogy szemléletmódbeli } \\
\text { váltásra ösztönözzék a lakosságot. } \\
\text { (They join national programmes and tenders; they plan litter } \\
\text { collection campaigns to encourage a change of attitude.) }\end{array}$ & $\begin{array}{l}\text { Abasár, Gyöngyös, Gyöngyöspata, } \\
\text { Gyöngyössolymos, Gyöngyöstarján, } \\
\text { Mátraszentimre, Nagyfüged, Nagyréde, } \\
\text { Pálosvörösmart, Vámosgyörk, Visonta }\end{array}$ \\
\hline $\begin{array}{l}\text { Nem támogatják a helyi szintü környezetvédelmet. } \\
\text { (They do not support environmental protection at local level.) }\end{array}$ & $\begin{array}{l}\text { Atkár, Adács, Domoszló, Gyöngyöshalász, } \\
\text { Gyöngyösoroszi, Halmajugra, Kisnána, } \\
\text { Ludas, Vécs }\end{array}$ \\
\hline
\end{tabular}

Megjegyzés: Egy település több tényezönél is szerepelhet!

Forrás: Saját kutatás és szerkesztés, 2020

A táblázat első tényezője leginkább az óvodákat és iskolákat érinti - Gyöngyös esetében a Magyar Agrár- és Élettudományi Egyetemet is, de ez nem került bele a táblázatba, mint általános jellemző -, amelyek szemétszedés által, környezetvédelmi programokkal járulnak hozzá a gyermekek tudatos neveléséhez. A kapott eredmények szerint, ez a tényező az önkormányzatok (és a hozzájuk tartozó települések) 40\%-ára jellemző. A második tényező a helyi lakosságra vonatkozik, amely odafigyel a környezetvédelemre, illetve az önkormányzatok is támogatják egyfajta elkülönített környezetvédelmi finanszírozási alappal. Ez a tényező az önkormányzatok 32\%-ára jellemző valamilyen formában. A harmadik tényező az országos programokra, pályázatokra vonatkozik, illetve a szemétgyüjtési akciók megtervezésére, amellyel ösztönözni szeretnék a lakosságot a mihamarabbi szemléletmód váltásra. Ez a tényező a leginkább jellemző a vizsgált településekre, mivel 44\%-uk mondta azt, hogy ez fontos.

Az utolsó tényező azokat a településeket érinti, amelyek valamilyen okból kifolyólag nem tudják támogatni a helyi szintü környezetvédelmet (pl. finanszírozásbéli problémák, infrastrukturális hiányosságok, a település elhelyezkedése stb.). Ez a tényező a települések $36 \%$-át érinti, amely véleményem szerint soknak számít, mivel a járás esetében a települések több mint egy egyharmada nem járul hozzá ilyen formában a környezetvédelemhez. A későbbi kutatásaim során tervezem, hogy további járásokat is hasonló szintü, reprezentatív felméréssel vizsgáljak (például Heves megye további járásait: Bélapátfalvai, járás, Egri járás, Füzesabonyi járás, Hatvani járás, Hevesi járás, Pétervásárai járás), így egy teljes képet fogok kapni a Heves megyére leginkább jellemző tényezők érvényesülésének szintjéről, amely segítségével könnyebben megállapíthatóvá válik, hogy mely településeknek vagy járásoknak van nagyobb szükségük a fejlödés elösegítésére.

A következö, összetettebb kérdés esetében érdekelt, hogy a térségi/települési fejlesztési stratégiában szerepelnek-e megújuló energiával kapcsolatos dolgok vagy témakörök, és ha igen, akkor milyen formában, illetve milyen fó céljai vannak. A kapott eredményeket rendszerezve mutatom be témakörök szerint, mivel ennél a kérdésnél nincs jelentősége a településekre való lebontásnak, de érdemes megemlíteni, hogy a 6. táblázat: „Nem támogatják a helyi szintü környezetvédelmet" tényezőnél szereplö települések esetében nem szerepel a fejlesztési stratégiában megújuló energiára vonatkozó beruházás. A további 16 település esetében az alábbi témakörök szerepelnek a fejlesztési stratégiában a megújuló energiára vonatkozóan:

- új szállodák, intézmények építése, amelyek mind megújuló energia segítségével épülnek;

- klímastratégia szintjén szerepelnek, mivel az aprítékos fütés bevezetése (2014-től) már nem versenyképes a napelemekkel szemben;

- a mátrai régióhoz tartozó önkormányzatok szövetségének szervezésében szerepelnek a megújuló energiára vonatkozó fejlesztések, melynek legfőbb célja: a különféle megújuló energiaforrások hasznosítása a településeket érintő, minden lehetséges alternatívát felhasználó fejlesztések megvalósítása;

- különböző versenyszférában jelenlevő vállalatok támogatása, amelyek szerves része a naperömü park (pl. Jász-Plasztik, $\mathrm{P} \& \mathrm{G}$ ). 
Jól látható tehát, hogy az önkormányzatok többsége fontosnak tartja a megújuló energia témakörére vonatkozó beruházásokat a települési fejlesztési stratégiájában, amelyet nem csak a jövőbeni pályázatok, beruházások mértékével vagy nagyságával próbál motiválni, de támogatják a helyi szintü, lakosságra vonatkozó megújuló energiaforrások használatát. Az erre a kérdésre kapott eredmények megoszlás (6. ábra) érdekesnek mondható, amelyből három csoportot különítettem el. Az első (60\%), azokat az önkormányzatok érinti, akik különböző módszerek segítségével támogatják a megújuló energia használatát. Ilyen módszerek például, hogy a pályázókat nyilatkozatokkal támogatják lakossági pályázat esetén, vagy napelem telepítése, biomassza, kazán használata esetén hozzájárulnak a költségek egy bizonyos hányadának fedezéséhez. A második csoportba (24\%) azok az önkormányzatok tartoznak, akik nem támogatják, aminek legföbb indoka, hogy nincs elkülönített pénze rá az önkormányzatoknak. A harmadik csoportba (16\%) pedig azok az önkormányzatok tartoznak, akiknek nincs semmilyen tudomása róla, hogy lennének ilyen kezdeményezéseik.

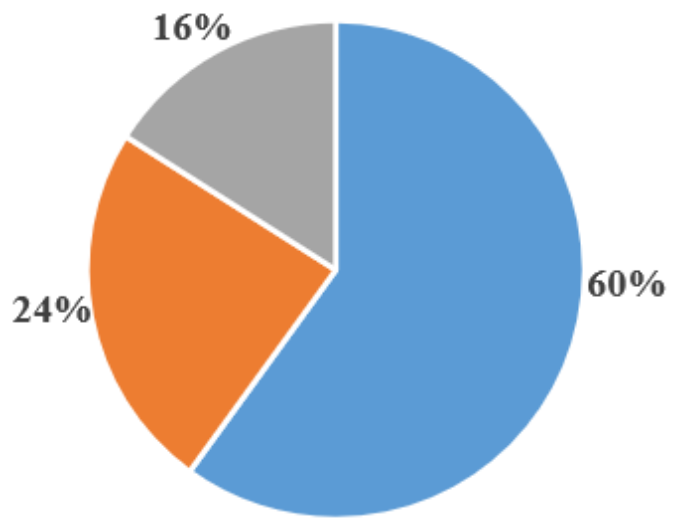

- Igen, támogatja.

(Yes, it supports.)

- Nem támogatja.

(No, it does not support.)

- Nincs tudomása róla.

(It is not aware of it.)

\section{6. ábra: A megkérdezett önkormányzatok megoszlása aszerint, hogy támogatják-e helyi szinten a megújuló energia használatát (\%)}

Figure 6. Distribution of the surveyed local governments according to whether they support the use of renewable energy at the local level (\%)

Forrás: Saját kutatás és szerkesztés, 2020

Az előző témához kapcsolódik a kérdőív következő kérdése, hogy az önkormányzatok hogyan látják a lakosság megújuló energiával kapcsolatos akcióit (7. ábra). A 6. ábrával összehasonlítva rögtön láthatóvá válik, hogy annak ellenére, hogy az önkormányzatok 40\%-a nem támogatja, vagy nincs tudomása a helyi szintü megújuló energiák használatával kapcsolatban, a lakosság akcióit jobban tolerálják, illetve több segítséget tudnak nyújtani - pl. a pályázó rendelkezik a megfelelő önerővel, hogy megvalósítsa a pályázatban leírt kritériumokat - mivel ebben az esetben az önkormányzatok 24\%-ának nincs tudomása semmilyen lakosságot érintő, megújuló energiára vonatkozó akcióról. A 76\% esetében tudnak ezekröl, amelyek az alábbiakat érintik: az utóbbi években (2-5 év) sok lakossági beruházás történt, pl. napelemekre, napkollektorokra, biomasszára vonatkozóan, amelyek családi házak tetején vagy az udvaron (kertben) valósultak meg; társasházak számára nyílászáró, hőszigetelés komplett renoválása - segítséget kell nyújtani a tender megvalósításakor, mivel a kisebb pályázatok sok ember számára érthetetlenek; komposztládákra, szelektív hulladékgyüjtésre hirdetett akciók, amelyekkel még inkább ösztönözni szeretnék a lakosságot ezek használatára. 


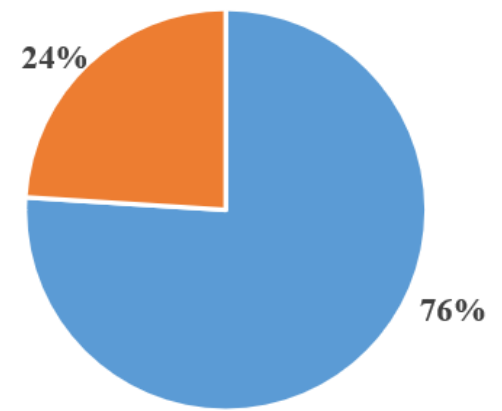

- Vannak ilyen akciók.

(There are such actions.)

- Nincs tudomása róla.

(It does not aware of it).

7. ábra: A megkérdezett önkormányzatok megoszlása, aszerint, hogy miként látják a lakosság megújuló energiával kapcsolatos akcióit (\%)

Figure 7. Distribution of the surveyed local governments according to how they see the population's actions related to renewable energy (\%)

Forrás: Saját kutatás és szerkesztés, 2020

A 8. ábrán látható eredmények a lakossággal, más településekkel való kommunikációra vonatkoznak. A kutatás során érdekelt, hogy vajon az önkormányzatok mennyire használják ki az online kommunikáció és a közösségi médiában rejlő lehetőségeket, hogy további fejlesztéseket eszközöljenek, illetve, hogy a lakosság helyzetét könnyítsék. A kutatás során kiderült, hogy bár az utóbbi években jelentős mértékben csökkent, de még mindig van relevanciája az írott sajtónak is.

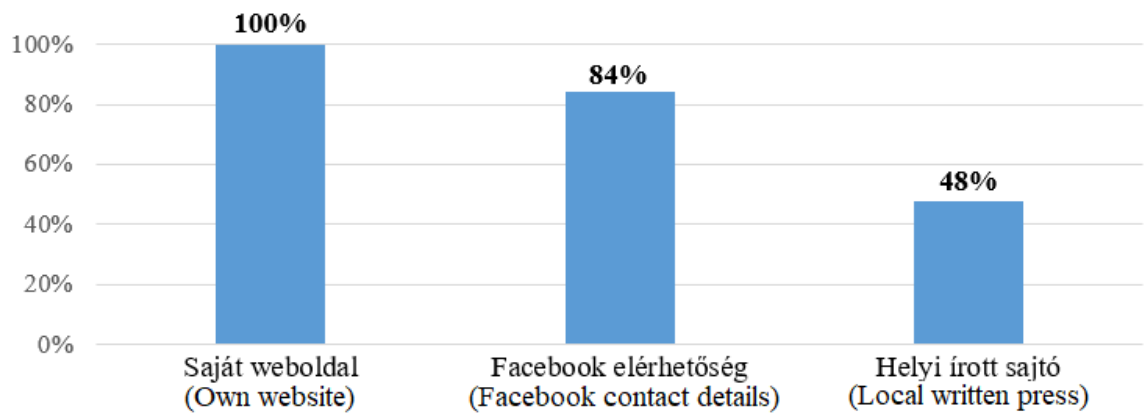

\section{8. ábra: A vizsgált önkormányzatok megoszlása a lakossággal történő kommunikációra használt eszközök alapján (\%)}

Figure 8. Distribution of the examined local governments on the basis of the means used for communication with the population (\%)

Megjegyzés: Több válasz is megjelölhetö volt!

Forrás: Saját kutatás és szerkesztés, 2020

Az eredményeket tekintve, mindenképpen pozitív, hogy minden település rendelkezik saját weboldallal, amelyen a felhasználó tájékozódhat nem csak a település elérhetőségeiröl, de olvashat a település hagyományairól, természeti adottságairól, növény- és állatvilágáról vagy akár külön böngészhet a dokumentumtár fül alatt a helyi önkormányzati rendeleteket érintő változásokról, helyi építési szabályzatokról vagy a települési arculati kézikönyvről is.

Néhány kivételtől eltekintve (pl. Halmajugra), a legtöbb esetben külön pályázatfigyelö rendszer is tartozik a weboldalakhoz, ahol mindenki számára elérhető az éppen folyamatban lévő pályázatok listája (pl. Adács Önkormányzat közintézményeinek energetikai korszerüsítése megújuló energiaforrás bevonásával, 2018.04.24-től, vagy a gyöngyöspatai Művelődési Ház és Polgármesteri Hivatal épületének energetikai korszerüsítése, 2019.06.27-től), és a már 
megvalósultak pályázatoké is. A közösségi média platformok közül az önkormányzatok $84 \%$ a használja a Facebook-ot, amely esetben külön csoportokat hoztak létre, ahol aktív fórum jellegként, akár rögtön is tudnak válaszolni a lakosság kérdéseire. Itt két variáns közül választhat a felhasználó; vagy csatlakozik az adott település csoportjához (korlátlan csoporthoz lehet csatlakozni a Facebook esetében), és ott különálló hozzászólásként tudja feltenni a kérdéseit/vagy tud véleményt nyilvánítani, illetve a másik opció, ha profilként van regisztrálva az adott település/önkormányzat a platformon, akkor privát üzenetben tudja megírni a felhasználó a véleményét vagy kérdéseit az önkormányzat számára, amely hétköznapokon munkaidőben, azonnali válaszadási lehetőséget biztosít az ott dolgozók számára. A harmadik eszköz, amelyet szívesen használnak továbbra is az önkormányzatok a helyi írott sajtó (48\%), amely a három eszköz közül mára már a leglassabb formának tekinthető.

Ehhez a kérdéshez kapcsolódik még az önkormányzati kérdőív utolsó kérdése, amely arra vonatkozik, hogy figyelik-e a megújuló energiával kapcsolatos információkat. Az önkormányzatok többségéről (88\%-ról) elmondható, hogy folyamatosan figyelik ezeket a lehetöségeket többféle platformon is. A válaszok között szerepelt továbbá, hogy külön energetikai lapokban, pályázatfigyelő weboldalokon, online közösségi felületeteken próbálják nyomon követni ezeket, illetve külön személyt alkalmaznak az önkormányzatnál, aki minden ezzel kapcsolatos információt, pályázatot és hírt figyel.

\section{Következtetések}

A fenntarhatóság szerepe, valamint a megújuló, tiszta és megfizhethető energiák fokozottabb használata egyértelmüen releváns kutatási területek napjainkban. Ezen témakörök elemzése és az ezzel kapcsolatos egyre gyakoribb távlati célok megfogalmazása még nagyobb szerepet fognak kapni a következő időszakban. Az Európai Unió fenntarthatóságot és környezettudatosságot elősegítő céljai is világosak és előremutatóak, amelyet nem csak az Európa 2020 stratégiai célkitüzései erősítettek meg az előző programozási időszakban, de az Agenda 2030 által bemutatott új integrált fenntartható fejlődési és fejlesztési keretrendszer is alátámaszt.

A fenntarthatósághoz és környezettudatossághoz kapcsolható pozitív értékek fejlesztése, újabb beruházások megpályázása és kivitelezése, különböző célcsoportok megközelítésével és bevonásával érhető el. Egyik ilyen célcsoport lehet a fiatal generáció tagjai, mint például az óvodások, általános- és középiskolás diákok vagy főiskolás/egyetemi hallgatók, akik esetében minél hamarabb érdemes megkezdeni a környezettudatosság fontosságának hangsúlyozását. Másik releváns célcsoport lehet a városok, községek és falvak helyi lakosai, akik szintén jelentős mértékben hozzá tudnak járulni a környezettudatossághoz és a környezetvédelemhez. Ehhez azonban szükség van a települések helyi önkormányzatainak támogatására is, akik nem csak releváns információval tudják ellátni a lakosságot - köztük a fiatalokat is -, de ösztönző erővel és legfőképp, példamutatással szolgálnak azok számára, akik megújuló energiával kapcsolatos beruházásokat szeretnének megpályázni az adott településeken. Ennek egyik módszere a személyes segítségnyújtás vagy tanácsadás, a másik pedig, a már most is jól müködő online rendszereken keresztüli elérhetöségek igénybevétele.

A járás szintü reprezentatív kutatásomban leginkább az önkormányzatok környezeti szerepére, megújuló energiára vonatkozó beruházásainak fajtáira, annak mértékeire, illetve a környezetvédelemre fókuszáló tényezők elemzésére tértem ki. Így, a kutatási eredmények összegzése és a hipotézisek összevetése után az alábbi egyértelmü következtetések fogalmazhatóak meg. 
A H1 igazoltnak tekinthető, vagyis a helyi önkormányzatok valóban határozott szerepet játszanak a lakosság környezettudatosságának és környezetvédelemmel kapcsolatos hozzáállásának a befolyásolásában a vizsgált térségben. Erre példa, hogy az önkormányzatok többségénél már több megújuló energiával kapcsolatos beruházás megvalósult, illetve folyamatosan napirendi ponton van a jövőbeni fejlesztések megvalósítása is (pl. LED izzók használata, kazánok cseréje) 500 ezer Ft-tól egészen 100 millió Ft fölötti nagyságrendig.

A $\mathrm{H} 2$ részben igazoltnak tekinthető, mivel az önkormányzatok esetében a kutatás alapján a jellemzően kis összegü, de mégis megvalósított, megújuló energiával kapcsolatos beruházások négyötöde terület/vidékfejlesztési forrásból valósult meg. Ebböl a szempontból a kérdéses programok hozzájárulása mégis csak kimutatható. Ha ehhez hozzávesszük azt az eredményt, hogy a témához kapcsolódó önkormányzati akciók és beruházások hatással vannak a lakossági környezettudatosság erösítésére, akkor a programok hozzájárulása az Unió - és Magyarország - környezeti céljaihoz nem cáfolható. Ezek alapján mindenképpen javasolt a pályázati rendszerek és lehetőségek szinkronizálása az eredményekhez, az önkormányzatok fokozottabb támogatása, valamint az online kommunikációs rendszerek bevonása.

A hipotézisek elemzésére vonatkozó eredményeken kívűl, fontosnak tartom kiemelni például azt is, hogy a vizsgált 25 település közül mintegy $48 \%$ esetében sokkal rosszabb a levegő minősége a fütési időszakban, mint fütési időszakon kívül. Ez már egy régóta fennálló probléma a járásban, melynek megoldása lehetne, ha először az érintett települések lakóit fokozottabb mértékben tájékoztatnák a levegőszennyezés kockázatairól, valamint annak rövid- és hosszútávú egészségügyi hatásairól. Második lépésként ösztönözni kellene a lakosságot, hogy a rossz minőségű szén (pl. lignit, amely jelentős mértékü negatív egészségügyi hatással is rendelkezik), a müanyag vagy egyéb hulladékkal való tüzelés helyett, inkább jó minőségü fával vagy földgázzal fütsenek, mivel ezek inkább tekinthetők környezetbarátnak $\left(\mathrm{a} \mathrm{CO}_{2}\right.$-kibocsátást leszámítva).

A megkérdezett önkormányzatoknál a megújuló energiák használatának helyi szintü támogatása esetében is nagyobb mértékü javulásra lenne szükség, mivel a megkérdezett 25 önkormányzat közül 24\% egyáltalán nem támogatja ezeket a beruházásokat, illetve további $16 \%$-nak nincs is tudomása ezekről. Ennek egyik megoldása lenne, ha olyan hazai vagy Európai Uniós pályázati forrásokat vennének igénybe, amelyek megfelelő mértékben tudnák támogatni ezeket a helyi szintü megújuló energiával kapcsolatos beruházások megvalósulását. Az önkormányzatok már megvalósult, illetve a jövőbeni környezettudatosságot és környezetvédelmet érintő beruházásai, és eképpen példamutatása, továbbra is fontos szerepet fognak játszani a lakosság ezen témák iránti megítélésében és hozzájárulásában.

\section{Hivatkozott források}

1. BNPI (2020): Bükki Nemzeti Park Igazgatóság. Forrás: https://www.bnpi.hu/hu/matraitajvedelmi-korzet. Letöltés dátuma: 2020.09.25.

2. ČERYOVÁ, D. - BULLOVÁ, T. - TURČEKOVÁ, N. - ADAMIČKOVÁ, I. MORAVČÍKOVÁ, D. - BIELIK, P. (2020): Assessment of the renewable energy sector performance using selected indicators in european union countries. Resources, 9(9) 102. DOI: $10.3390 /$ resources 9090102

3. EURÓPAI BIZOTTSÁG (2020): Fenntartható Fejlődési Célok (SDGs). Forrás: https://ec.europa.eu/info/strategy/international-strategies/sustainable-developmentgoals/eu-and-united-nations-common-goals-sustainable-future_en. Letöltési dátum: 2020. 09.04 
4. GKF development (2020): Uniós pályázatok fajtái. Forrás: http://uniospalyazatok.gkf.hu/. Letöltési dátum: 2020.09.11.

5. HILARY, F. (2000): Vanishing Borders: Protecting the Planet in the Age of Globalization. New York, USA: World Watch Institute.

6. KEREKES S. - SZLÁVIK J. (2003): A környezeti menedzsment közgazdasági eszközei. Budapest: Complex Kiadó.

7. MARJAINÉ Széchy Zs. - Zsóka Á. - Széchy A. (2012): Környezettudatosak-e a középiskolások? In: Kerekes S. - Csutora M. (szerk.): Fenntartható fogyasztás? Trendek és lehetőségek Magyarországon. Budapest: AULA Kiadó, pp. 225-258.

8. SZABÓ M. - KISS Á. (2017): Effects of renewable energy resources on the landscape. Hungarian Geographical Bulletin, 63(1), 5-16. DOI:10.15201/hungeobull.63.1.1

9. SZAMEK G. (2017): Az EU klímavédelmi törekvései, különös tekintettel az Európa 2020 stratégiára és Párizsra. Közép-Európai Közlemények, 10(2), 182-195.

10. SZEBERÉNYI, A. (2018): Representative primary research about renewable energy investments in case of the local governments located in the micro-region of Gyöngyös. Visegrad Journal on Bioeconomy and Sustainable Development, 7(2), 51-56. DOI:10.2478/vjbsd-2018-0010

11. TAKÁCS-GYÖRGY, K. - DOMÁN, Sz. - TAMUS, A. - HORSKÁ, E. - PALKOVÁ, Z. (2015): What do the youth know about alternative energy sources - case study from Hungary and Slovakia. Visegrad Journal on Bioeconomy and Sustainable Development, 4(2), 36-41. DOI: 10.1515/vjbsd-2015-0009

12. TEIR (2020): Országos Területfejlesztési és Területrendezési Információs Rendszer. Forrás: https://www.teir.hu/helyzet-ter-kep/. Letöltési dátum: 2020.10.12.

13. UNITED NATIONS (2021): Transforming our world - The 2030 Agenda for Sustainable Development. Forrás: https://sdgs.un.org/2030agenda. Letöltési dátum: 2021.02.04.

\section{Szerző:}

\section{Dr. Szeberényi András, PhD}

egyetemi adjunktus

Budapesti Metropolitan Egyetem, Turizmus és Marketing Intézet

1148 Budapest, Nagy Lajos király útja 1-9.

andras.szeberenyi@gmail.com 